BIOMEDICAL AND BIOSOCIAL ANTHROPOLOGY
Official Journal of the International Academy
of Integrative Anthropology
journal homepage: http://bba-journal.com

\title{
Correlations of anthropo-somatotypological indicators with indicators of personality traits of practically healthy Ukrainian women
}

\author{
Andriievskyi I. I. ${ }^{1}$, Serebrennikova O. A. ${ }^{1}$, Gunas I. V. ${ }^{1}$, Cherkasova O. V. ${ }^{2}$, Kyrychenko V. I. ${ }^{1}$ \\ ${ }^{1}$ National Pirogov Memorial Medical University, Vinnytsya, Ukraine \\ ${ }^{2}$ Bogomolets National Medical University, Kyiv, Ukraine
}

\section{ARTICLE INFO}

Received: 13 September, 2019

Accepted: 16 October, 2019

UDC: $572.087: 159.922$

\section{CORRESPONDING AUTHOR}

e-mail: oserebrennikova1@gmail.com Serebrennikova O. A.
The purpose of the work is to determine and analyze the peculiarities of correlations between the constitutional parameters of the body and personality indicators of practically healthy Ukrainian women of the first mature age. Primary anthropo-somatotypological (anthropometric examination according to the scheme of V. V. Bunak, determination of somatotype - according to the mathematical scheme of J. Carter and B. Heath; determination of fat, bone and muscle components of body weight - according to the formulas of J. Matiegka, determination of muscular components of body weight according to the method of the American Institute of Nutrition) and indicators of personality (leading typological characteristics of temperament according to Eysenck, psychodynamic features of personality according to Spielberger, indicators of severity and features of accentuated personality traits according to Shmishek, indicators of subjective control according to Rotter) of 101 practically healthy Ukrainian women of the first mature age were selected from the data bank of materials of the research center of National Pirogov Memorial Medical University, Vinnytsya. The analysis of correlations between anthropo-somatotypological indicators and indicators of personality traits was performed in the licensed package "Statistica 6.1" using the statistical method of Pearson. Between anthropo-somatotypological indicators and indicators of personality traits of practically healthy Ukrainian women, mostly single weak-strength feedback and direct reliable correlations have been established. In most cases, the feedback is established with the leading typological characteristics of temperament according to Eysenck, psychodynamic features of personality according to Spielberger and indicators of severity and features of accentuated personality traits according to Shmishek, and direct - with indicators of subjective control according to Rotter. The multiple nature of the relationship only between the rate of accentuation of the character of the exalted type according to Shmishek with most indicators of the width of the distal epiphyses of the limbs and the size of the pelvis; between the level of subjective control in the field of failures according to Rotter with half the longitudinal sizes of the body; between the indicator of situational (reactive) anxiety according to Spielberger, or the indicator of accentuation of the character of the cyclothymic type according to Shmishek with all the girths of the chest. Quantitative analysis of significant correlations between anthropo-somatotypological indicators and indicators of personality traits of practically healthy Ukrainian women revealed the largest relative percentage of reliable correlations of anthropo-somatotypological indicators. Namely, with the leading typological characteristics of temperament according to Eysenck, the largest relative percentage of reliable relationships was established with transverse body size and somatotypological indicators; with psychodynamic features of the personality according to Spielberger - with somatotypological indicators; with indicators of severity and features of accentuated personality traits according to Shmishek - with longitudinal body dimensions, cephalometric indicators and width of distal epiphyses of extremities; with indicators of the level of subjective control according to Rotter - with longitudinal body size and somatotypological indicators. 
Keywords: correlations, anthropometric and somatotypological indicators, indicators of personality traits, practically healthy women of the first mature age.

\section{Introduction}

Health is defined by the World Health Organization (WHO) as a state of complete physical, social and mental wellbeing. All these three components of health (ie health care) of the population are one of the most important tasks of every civilized state. However, this goal cannot be fully achieved without a holistic understanding of the relationships between the various individual properties of the organism, all its systems. One of the components of health that causes the greatest concern in the $\mathrm{WHO}$ is mental well-being. As of 2001, the organization estimates that about 450 million people suffer from mental disorders [30].

Psychological qualities, like other parts of the human constitution, are formed under the influence of both external and internal factors (genetic potential of a person). That is, there is a relationship between anthropo-somatotypological and psychological indicators of man. Thus, domestic and foreign scientists have conducted a number of studies in which such connections have been established both for healthy categories of people [16] and for some psychiatric diseases [3, 15, 21].

However, in order to lay a solid foundation in further research to find correlations between body structure and mental personality, it is first necessary to conduct research on a healthy population, considering ethnic, age and gender factors.

The aim of the work is to determine and analyze the peculiarities of correlations between the constitutional parameters of the body and the personality indicators of practically healthy Ukrainian women of the first mature age.

\section{Materials and methods}

Primary anthropo-somatotypological and personality indicators of practically healthy Ukrainian women $(n=101)$ of the first mature age (from 21 to 35 years) were selected from the database of materials of the research center of National Pirogov Memorial Medical University, Vinnytsya.

Anthropometric survey was conducted according to the scheme of V. V. Bunak [4]; somatotype determination according to the mathematical scheme of J. Carter and B. Heath [5]; determination of fat, bone and muscle components of body weight - according to the formulas of J. Matiegka [17]; in addition, the muscle component of body weight - according to the method of the American Institute of Nutrition (AIN) [29].

The study of individual-personal properties of the organism was carried out with the help of personal questionnaires, namely: evaluation of the leading typological characteristics of temperament according to Eysenck; determination of psychodynamic features of the personality according to Spielberger C. D in modification of Khanin Yu. L.; assessment of the severity and features of accentuated personality traits by Shmishek G.; determination of the components of internality according to Rotter J. in the modification of Bazhin E. F., Golinkina S. O. and Etkind O. M. [6, 7, 9, 14, 18, 24, 25].

The analysis of correlations between anthroposomatotypological indicators and indicators of personality traits was performed in the licensed package "Statistica 6.1 " using the statistical method of Pearson.

\section{Results}

Table 1 presents the results of correlations between the constitutional parameters of the body of practically healthy women with the leading typological characteristics of temperament (according to Eysenck G.) and psychodynamic features of personality (according to Spielberger C. D. in the modification of Khanin Y. L.).

Table 2 presents the results of correlations between the constitutional parameters of the body of practically healthy women with the severity and features of accentuated personality traits (according to G. Shmishek).

Table 3 presents the results of correlations between the constitutional parameters of the body of practically healthy women with indicators of the level of subjective control (according to Rotter J. in the modification of Bazhin E. F., Golinkina S. O. and Etkind O. M.).

Table 1. Correlations of anthropo-somatotypological indicators with the leading typological characteristics of temperament and psychodynamic features of the personality of practically healthy women $(n=101)$.

\begin{tabular}{|c|c|c|c|c|c|}
\hline \multirow{2}{*}{$\begin{array}{c}\text { Body } \\
\text { parameters }\end{array}$} & \multicolumn{3}{|c|}{$\begin{array}{c}\text { Characteristics of } \\
\text { temperament }\end{array}$} & \multicolumn{2}{c|}{$\begin{array}{c}\text { Psychodynamic } \\
\text { features of personality }\end{array}$} \\
\cline { 2 - 6 } & AZ_E & AZ_N & AZ_L & SP_ST & SP_LT \\
\hline OB_GL & -0.06 & -0.11 & -0.10 & 0.01 & 0.01 \\
\hline B_DL_GL & -0.09 & -0.08 & 0.21 & -0.07 & -0.07 \\
\hline N_SH_GL & 0.06 & -0.10 & -0.02 & -0.06 & -0.11 \\
\hline SH_N_CH & -0.07 & 0.04 & 0.04 & -0.02 & 0.11 \\
\hline SAG_DUG & -0.09 & -0.06 & -0.01 & -0.04 & -0.06 \\
\hline B_SH_GL & -0.28 & -0.04 & 0.17 & 0.03 & 0.09 \\
\hline SH_LICA & -0.11 & -0.04 & -0.03 & 0.11 & 0.10 \\
\hline W & -0.15 & -0.19 & 0.15 & -0.16 & -0.13 \\
\hline H & -0.05 & -0.17 & 0.04 & 0.03 & 0.00 \\
\hline ATND & -0.02 & -0.17 & -0.02 & 0.05 & 0.02 \\
\hline ATL & -0.08 & -0.02 & -0.03 & 0.03 & 0.05 \\
\hline ATPL & -0.08 & -0.18 & -0.02 & 0.03 & 0.00 \\
\hline ATP & -0.02 & -0.22 & 0.10 & -0.06 & -0.16 \\
\hline ATV & -0.15 & -0.04 & 0.01 & 0.06 & -0.06 \\
\hline EPPL & -0.04 & -0.06 & 0.12 & -0.19 & -0.14 \\
\hline EPPR & 0.07 & -0.16 & 0.16 & -0.09 & -0.15 \\
\hline EPB & -0.09 & -0.08 & 0.13 & -0.12 & -0.08 \\
\hline & & & & & \\
\hline
\end{tabular}


Continuation of table 1.

\begin{tabular}{|c|c|c|c|c|c|}
\hline \multirow{2}{*}{$\begin{array}{c}\text { Body } \\
\text { parameters }\end{array}$} & \multicolumn{3}{|c|}{$\begin{array}{c}\text { Characteristics of } \\
\text { temperament }\end{array}$} & \multicolumn{2}{|c|}{$\begin{array}{l}\text { Psychodynamic } \\
\text { features of personality }\end{array}$} \\
\hline & AZ_E & AZ_N & AZ_L & SP_ST & SP_LT \\
\hline EPG & 0.07 & -0.10 & 0.19 & -0.17 & -0.04 \\
\hline $\mathrm{OBPL}_{1}$ & -0.09 & -0.04 & 0.17 & -0.14 & -0.08 \\
\hline $\mathrm{OBPL}_{2}$ & -0.08 & -0.07 & 0.17 & -0.17 & -0.12 \\
\hline $\mathrm{OBPR}_{1}$ & -0.12 & -0.16 & 0.12 & -0.17 & -0.17 \\
\hline $\mathrm{OBPR}_{2}$ & -0.20 & -0.10 & 0.14 & 0.03 & -0.04 \\
\hline OBB & -0.03 & -0.10 & 0.23 & -0.24 & -0.09 \\
\hline $\mathrm{OBG}_{1}$ & -0.14 & -0.09 & 0.12 & -0.17 & -0.06 \\
\hline $\mathrm{OBG}_{2}$ & -0.22 & 0.01 & -0.02 & 0.00 & 0.05 \\
\hline $\mathrm{OBSH}$ & -0.11 & -0.20 & -0.01 & -0.11 & -0.14 \\
\hline OBT & -0.12 & -0.04 & 0.10 & -0.12 & -0.04 \\
\hline OBBB & -0.09 & -0.09 & 0.18 & -0.10 & -0.06 \\
\hline OBK & -0.16 & -0.06 & 0.22 & -0.16 & -0.07 \\
\hline OBS & -0.15 & 0.01 & 0.17 & -0.09 & 0.02 \\
\hline $\mathrm{OBGK}_{1}$ & 0.10 & -0.12 & 0.14 & -0.28 & -0.20 \\
\hline $\mathrm{OBGK}_{2}$ & 0.07 & -0.13 & 0.19 & -0.30 & -0.19 \\
\hline $\mathrm{OBGK}_{3}$ & 0.10 & -0.15 & 0.17 & -0.30 & -0.20 \\
\hline PSG & 0.02 & -0.18 & 0.11 & 0.00 & -0.02 \\
\hline PNG & 0.11 & -0.23 & 0.09 & -0.02 & -0.04 \\
\hline SGK & -0.06 & -0.08 & 0.07 & -0.21 & -0.11 \\
\hline ACR & 0.02 & -0.05 & 0.04 & 0.01 & 0.12 \\
\hline SPIN & -0.03 & -0.11 & 0.03 & 0.07 & 0.04 \\
\hline CRIS & 0.09 & 0.01 & 0.11 & -0.11 & -0.03 \\
\hline TROCH & -0.05 & -0.12 & 0.08 & -0.08 & 0.01 \\
\hline CONJ & -0.22 & -0.07 & 0.14 & -0.11 & -0.08 \\
\hline GZPL & -0.06 & -0.10 & 0.10 & -0.10 & -0.09 \\
\hline GPPL & -0.12 & -0.18 & 0.10 & -0.08 & -0.11 \\
\hline GPR & -0.09 & -0.13 & 0.02 & -0.04 & -0.08 \\
\hline $\mathrm{GL}$ & -0.11 & -0.04 & 0.16 & -0.08 & -0.06 \\
\hline GGR & -0.01 & -0.16 & 0.07 & -0.21 & -0.14 \\
\hline GG & 0.04 & 0.05 & 0.10 & -0.12 & -0.03 \\
\hline GB & 0.04 & -0.12 & 0.10 & -0.21 & -0.18 \\
\hline GBD & 0.00 & -0.02 & 0.10 & -0.10 & -0.07 \\
\hline GGL & -0.02 & 0.03 & 0.14 & -0.12 & -0.03 \\
\hline $\mathrm{FX}$ & -0.04 & -0.12 & 0.16 & -0.21 & -0.16 \\
\hline$M X$ & -0.08 & 0.01 & 0.14 & -0.19 & -0.10 \\
\hline LX & 0.07 & 0.05 & -0.11 & 0.21 & 0.17 \\
\hline SOMAT & 0.13 & -0.24 & -0.09 & -0.17 & -0.28 \\
\hline MM & -0.10 & -0.14 & 0.17 & -0.19 & -0.10 \\
\hline OM & 0.09 & -0.03 & 0.18 & -0.09 & -0.08 \\
\hline DM & -0.06 & -0.11 & 0.15 & -0.15 & -0.11 \\
\hline MA & -0.07 & -0.04 & 0.14 & -0.11 & -0.05 \\
\hline
\end{tabular}

Notes: here and in the following tables, the yellow background is a reliable weak correlation; green background - reliable medium correlation strength; red numbers - reliable direct correlation; blue numbers - reliable feedback; OB_GL - head circumference $(\mathrm{cm})$; B DL GL - the largest length of the head $(\mathrm{cm}) ; \mathrm{N} S \mathrm{SH}$ GL - the smallest width of the head $(\mathrm{cm})$; $\mathrm{SH} \mathrm{N}_{-} \mathrm{CH}$ - width of the lower jaw $(\mathrm{cm})$; SAG_DUG - sagittal arch (cm); B_SH_GL - the largest width of the head $(\mathrm{cm})$; SH_LICA - face width $(\mathrm{cm})$; W - body weight $(\mathrm{kg}) ; \mathrm{H}$ - body length $(\mathrm{cm})$; ATND - height of the upper thoracic point (cm); ATL - pubic point height $(\mathrm{cm})$; ATPL - height of the acromial point $(\mathrm{cm})$; ATP - height of the finger point $(\mathrm{cm})$; ATV height of the trochanter point $(\mathrm{cm})$; EPPL - width of the distal epiphysis of shoulder (cm); EPPR - width of the distal epiphysis of the forearm (cm); EPB - width of the distal epiphysis of the thigh $(\mathrm{cm})$; EPG - width of the distal epiphysis of the crus $(\mathrm{cm})$; $\mathrm{OBPL}_{1}$ shoulder girth in a tense state $(\mathrm{cm}) ; \mathrm{OBPL}_{2}$ - shoulder girth in the unstressed state $(\mathrm{cm})$; OBPR $\mathrm{OB}_{1}$ - forearm girth in the upper part $(\mathrm{cm}) ; \mathrm{OBPR}_{2}$ - forearm girth in the lower part $(\mathrm{cm})$; OBB - hip circumference $(\mathrm{cm}) ; \mathrm{OBG}_{1}$ - shin girth in the upper part $(\mathrm{cm}) ; \mathrm{OBG}_{2}$ - shin girth in the lower part $(\mathrm{cm})$; OBSH - neck circumference $(\mathrm{cm})$; OBT - waist circumference (cm); OBBB - hip circumference $(\mathrm{cm})$; OBK - girth of the hand $(\mathrm{cm})$; OBS - foot circumference $(\mathrm{cm})$; $\mathrm{OBGK}_{1}$ - chest girth on inspiration $(\mathrm{cm}) \mathrm{OBGK}_{2}$ - chest girth on exhalation $(\mathrm{cm}) ; \mathrm{OBGK}_{3}$ - chest girth with calm breathing $(\mathrm{cm})$; PSG - transverse mid-thoracic size $(\mathrm{cm})$; PNG - transverse lower chest size $(\mathrm{cm})$; SGK - anterior-posterior size of the chest $(\mathrm{cm})$; ACR - shoulder width $(\mathrm{cm})$; SPIN - interspinous distance $(\mathrm{cm})$; CRIS - intercristal distance $(\mathrm{cm}) ; \mathrm{TROCH}$ - intertrochanteric distance (cm); CONJ - external conjugate (cm); GZPL - thickness of skin and fat folds (TSFF) on a back surface of a shoulder (mm); GPPL - TSFF on a front surface of a shoulder $(\mathrm{mm})$; GPR - TSFF on a forearm $(\mathrm{mm})$; GL - TSFF under a shovel $(\mathrm{mm})$; GGR - TSFF on a breast $(\mathrm{mm})$; GG - TSFF on the abdomen $(\mathrm{mm})$; GB - TSFF on the side $(\mathrm{mm})$; GBD - TSFF on a thigh (mm); GGL - TSFF on a crus $(\mathrm{mm})$; FX - endomorphic component of the somatotype according to Heath-Carter (points); MX - mesomorphic component of the somatotype according to Heath-Carter (points); LX - ectomorphic component of the Heat-Carter somatotype (points); SOMAT somatotype according to Heat-Carter (relative units); MM -muscle mass according to Matiegka (kg); OM - bone mass according to Matiegka (kg); DM - fat mass according to Matiegka (kg); MA muscle mass, determined by the formula AIX (kg); AZ_E - index on the scale of extraversion-introversion according to Eysenck (points); $A Z \mathrm{~N}$ - indicator on the scale of neuroticism according to Eysenck (points); AZ_L - Eysenck insincerity scale (points); SP_ST - indicator of situational (reactive) anxiety according to Spielberger (points); SP_LT - indicator of personal anxiety according to Spielberger (points).

\section{Discussion}

In the analysis of significant correlations between anthropo-somatotypological indicators and indicators of personality traits of practically healthy Ukrainian women, mostly single inverse feedback ( $r=$ from -0.21 to -0.29 ) and direct ( $r=$ from 0.22 to 0.27 ) correlations were established. In most cases, the feedback of anthropo-somatotypological indicators in practically healthy women is established with the leading typological characteristics of temperament, psychodynamic personality traits and indicators of severity and features of accentuated personality traits, and direct with indicators of the level of subjective control. Attention is drawn to the multiple nature of the relationship only between the rate of accentuation of the character of the exalted type according to Shmishek with most indicators of the width of the distal epiphyses of the extremities and the size of the pelvis ( $r=-0.21$ to -0.28$)$; between the indicator of the level of 
Andriievskyi I. I., Serebrennikova O. A., Gunas I. V., Cherkasova O. V., Kyrychenko V. I.

Table 2. Correlations of anthropo-somatotypological indicators with indicators of severity and features of accentuated personality traits of practically healthy women $(n=101)$.

\begin{tabular}{|c|c|c|c|c|c|c|c|c|c|c|}
\hline \multirow{2}{*}{$\begin{array}{c}\text { Body } \\
\text { parameters }\end{array}$} & \multicolumn{10}{|c|}{ Indicators of severity and features of accentuated personality traits } \\
\hline & SH_G & SH_Z & SH_EM & SH_P & SH_T & $\mathrm{SH} \_\mathrm{C}$ & SH_DM & SH_V & SH_DC & SH_EK \\
\hline OB_GL & 0.03 & 0.05 & -0.07 & 0.12 & -0.10 & 0.04 & -0.03 & -0.11 & 0.02 & -0.11 \\
\hline B_DL_GL & -0.05 & 0.07 & 0.09 & 0.07 & -0.03 & -0.12 & -0.01 & -0.11 & -0.01 & -0.13 \\
\hline N_SH_GL & -0.02 & -0.21 & 0.15 & -0.06 & -0.07 & -0.19 & 0.14 & -0.09 & -0.07 & -0.13 \\
\hline $\mathrm{SH} \_\mathrm{N} \_\mathrm{CH}$ & -0.06 & -0.07 & 0.00 & 0.02 & -0.08 & -0.18 & 0.00 & -0.04 & 0.08 & 0.02 \\
\hline SAG_DUG & -0.06 & 0.04 & 0.10 & 0.06 & 0.04 & -0.02 & -0.13 & -0.12 & 0.04 & -0.24 \\
\hline B_SH_GL & -0.18 & -0.03 & 0.15 & 0.10 & 0.06 & -0.05 & -0.28 & -0.07 & 0.24 & -0.08 \\
\hline SH_LICA & 0.02 & 0.00 & 0.05 & 0.00 & 0.00 & -0.28 & 0.02 & -0.08 & 0.03 & -0.02 \\
\hline W & -0.01 & -0.02 & -0.06 & -0.01 & -0.15 & -0.19 & -0.12 & -0.07 & -0.07 & -0.19 \\
\hline $\mathrm{H}$ & -0.16 & -0.06 & -0.17 & -0.09 & -0.21 & -0.02 & -0.13 & -0.07 & 0.01 & -0.18 \\
\hline ATND & -0.14 & -0.14 & -0.19 & -0.08 & -0.19 & 0.00 & -0.13 & -0.04 & 0.00 & -0.17 \\
\hline ATL & -0.20 & -0.22 & -0.11 & 0.05 & -0.10 & 0.02 & -0.22 & -0.06 & 0.08 & -0.08 \\
\hline ATPL & -0.18 & -0.13 & -0.20 & -0.08 & -0.19 & 0.00 & -0.13 & -0.03 & -0.01 & -0.15 \\
\hline ATP & -0.08 & -0.09 & -0.25 & -0.09 & -0.25 & 0.03 & -0.14 & -0.05 & -0.09 & -0.10 \\
\hline ATV & -0.16 & -0.10 & -0.11 & -0.01 & -0.05 & -0.03 & -0.15 & -0.12 & 0.10 & -0.15 \\
\hline EPPL & -0.05 & -0.14 & 0.00 & -0.08 & -0.16 & -0.01 & -0.14 & -0.02 & -0.12 & -0.21 \\
\hline EPPR & 0.07 & -0.02 & -0.01 & -0.11 & -0.20 & -0.15 & -0.09 & 0.00 & -0.11 & -0.23 \\
\hline EPB & 0.08 & -0.04 & -0.07 & -0.14 & -0.10 & -0.02 & -0.04 & 0.05 & -0.09 & 0.01 \\
\hline EPG & 0.10 & -0.06 & 0.16 & -0.01 & -0.17 & 0.00 & -0.05 & -0.03 & -0.08 & -0.21 \\
\hline $\mathrm{OBPL}_{1}$ & 0.05 & 0.13 & -0.02 & 0.08 & -0.07 & -0.11 & -0.05 & 0.04 & -0.03 & -0.07 \\
\hline $\mathrm{OBPL}_{2}$ & 0.05 & 0.14 & -0.02 & 0.06 & -0.07 & -0.18 & -0.02 & 0.01 & -0.05 & -0.08 \\
\hline $\mathrm{OBPR}_{1}$ & 0.06 & 0.06 & 0.02 & 0.13 & -0.05 & -0.29 & -0.07 & -0.07 & -0.03 & -0.19 \\
\hline $\mathrm{OBPR}_{2}$ & 0.00 & 0.21 & 0.04 & 0.04 & 0.03 & -0.18 & -0.05 & -0.04 & 0.13 & -0.15 \\
\hline OBB & 0.02 & 0.06 & -0.02 & -0.01 & -0.13 & -0.10 & -0.08 & -0.02 & -0.14 & -0.14 \\
\hline $\mathrm{OBG}_{1}$ & -0.01 & 0.04 & 0.02 & -0.04 & -0.19 & -0.11 & -0.09 & -0.05 & -0.03 & -0.12 \\
\hline $\mathrm{OBG}_{2}$ & -0.18 & 0.05 & -0.12 & 0.09 & -0.16 & -0.03 & -0.24 & 0.10 & 0.23 & -0.07 \\
\hline OBSH & 0.04 & 0.04 & -0.01 & 0.00 & -0.12 & -0.25 & 0.02 & -0.09 & -0.06 & -0.19 \\
\hline OBT & -0.06 & 0.03 & -0.07 & 0.02 & 0.00 & -0.20 & -0.02 & 0.00 & -0.08 & -0.04 \\
\hline OBBB & -0.04 & 0.01 & -0.02 & -0.06 & -0.10 & -0.07 & -0.14 & -0.01 & -0.11 & -0.14 \\
\hline OBK & -0.03 & 0.06 & 0.15 & 0.02 & -0.11 & -0.17 & 0.00 & -0.01 & -0.03 & -0.11 \\
\hline OBS & -0.05 & -0.07 & 0.04 & -0.04 & -0.07 & -0.02 & -0.11 & -0.05 & 0.13 & -0.03 \\
\hline $\mathrm{OBGK}_{1}$ & 0.22 & 0.14 & 0.04 & -0.05 & 0.02 & -0.24 & 0.09 & -0.12 & -0.20 & -0.09 \\
\hline $\mathrm{OBGK}_{2}$ & 0.16 & -0.01 & 0.02 & -0.09 & -0.06 & -0.23 & 0.05 & -0.15 & -0.16 & -0.12 \\
\hline $\mathrm{OBGK}_{3}$ & 0.20 & 0.08 & 0.02 & -0.07 & -0.03 & -0.26 & 0.09 & -0.17 & -0.19 & -0.14 \\
\hline PSG & 0.08 & -0.03 & -0.11 & -0.05 & 0.01 & -0.19 & 0.06 & -0.06 & 0.03 & -0.17 \\
\hline PNG & 0.03 & -0.09 & -0.11 & -0.05 & -0.09 & -0.13 & 0.06 & -0.19 & -0.10 & -0.15 \\
\hline SGK & -0.10 & -0.25 & 0.01 & 0.02 & -0.06 & 0.00 & -0.05 & -0.11 & -0.02 & -0.12 \\
\hline ACR & 0.04 & -0.02 & -0.04 & -0.07 & 0.03 & 0.04 & -0.03 & -0.13 & 0.02 & -0.06 \\
\hline SPIN & -0.03 & -0.06 & 0.02 & -0.12 & 0.04 & -0.15 & -0.13 & 0.00 & 0.01 & -0.22 \\
\hline CRIS & -0.03 & -0.08 & 0.19 & -0.15 & 0.09 & -0.03 & -0.05 & -0.13 & -0.18 & -0.28 \\
\hline $\mathrm{TROCH}$ & -0.08 & -0.15 & 0.07 & -0.12 & -0.11 & -0.07 & -0.13 & -0.05 & -0.04 & -0.21 \\
\hline
\end{tabular}




\section{Continuation of table 2.}

Continuation of table 2.
\begin{tabular}{|c|c|c|c|c|c|c|c|c|c|c|}
\hline \multirow{2}{*}{$\begin{array}{c}\text { Body } \\
\text { parameters }\end{array}$} & \multicolumn{10}{|c|}{ Indicators of severity and features of accentuated personality traits } \\
\cline { 2 - 12 } & SH_G & SH_Z & SH_EM & SH_P & SH_T & SH_C & SH_DM & SH_V & SH_DC & SH_EK \\
\hline CONJ & -0.07 & 0.00 & 0.12 & 0.12 & 0.04 & -0.20 & -0.14 & -0.08 & 0.10 & -0.17 \\
\hline GZPL & -0.01 & -0.02 & -0.10 & -0.05 & -0.13 & 0.00 & -0.20 & -0.02 & -0.08 & -0.22 \\
\hline GPPL & -0.01 & -0.05 & -0.04 & 0.01 & -0.11 & 0.04 & -0.29 & -0.06 & -0.05 & -0.22 \\
\hline GPR & 0.01 & -0.06 & -0.13 & -0.01 & -0.09 & 0.05 & -0.15 & -0.01 & -0.11 & -0.18 \\
\hline GL & -0.06 & 0.05 & -0.10 & -0.12 & -0.06 & -0.03 & -0.08 & -0.05 & -0.01 & -0.15 \\
\hline GGR & 0.06 & -0.12 & 0.02 & -0.08 & -0.07 & -0.07 & -0.02 & -0.18 & -0.08 & -0.13 \\
\hline GG & 0.12 & 0.14 & 0.06 & -0.12 & 0.13 & -0.13 & 0.07 & 0.02 & -0.13 & -0.01 \\
\hline GB & 0.12 & 0.12 & -0.05 & -0.18 & 0.01 & -0.17 & 0.06 & -0.01 & -0.22 & -0.16 \\
\hline GBD & 0.07 & 0.18 & 0.11 & -0.03 & -0.10 & -0.04 & -0.03 & -0.05 & -0.05 & -0.02 \\
\hline GGL & 0.02 & 0.17 & 0.09 & -0.09 & -0.12 & 0.01 & -0.05 & -0.04 & -0.02 & 0.01 \\
\hline FX & 0.07 & 0.05 & -0.09 & -0.12 & -0.07 & -0.12 & -0.08 & -0.07 & -0.13 & -0.19 \\
\hline MX & 0.11 & 0.06 & 0.06 & 0.00 & -0.03 & -0.07 & -0.02 & 0.04 & -0.08 & -0.01 \\
\hline LX & -0.12 & -0.03 & -0.06 & -0.02 & -0.01 & 0.17 & 0.00 & 0.01 & 0.11 & 0.01 \\
\hline SOMAT & 0.13 & -0.04 & -0.11 & -0.06 & -0.22 & -0.12 & 0.13 & 0.00 & -0.20 & -0.10 \\
\hline MM & -0.02 & 0.03 & -0.06 & 0.03 & -0.15 & -0.18 & -0.08 & -0.04 & -0.07 & -0.18 \\
\hline OM & 0.06 & -0.08 & 0.00 & -0.05 & -0.12 & 0.05 & -0.13 & 0.03 & -0.08 & -0.16 \\
\hline DM & 0.03 & 0.09 & -0.02 & -0.10 & -0.13 & -0.08 & -0.10 & -0.03 & -0.11 & -0.19 \\
\hline MA & 0.03 & 0.13 & -0.01 & 0.09 & -0.08 & -0.11 & -0.01 & 0.03 & -0.01 & -0.05 \\
\hline
\end{tabular}

Notes: SH G - indicator of accentuation of character of hyperthymic type according to Shmishek (points); SH Z - indicator of accentuation of the character of the stuck type according to Shmishek (points); SH_EM - an indicator of accentuation of the character of the emotional type according to Shmishek (points); SH_P - indicator of accentuation of character of pedantic type according to Shmishek (points); SH_T - indicator of character accentuation of anxiety type according to Shmishek (points); SH_C - Shmishek character accentuation index of cyclothymic type (points); SH DM - indicator of accentuation of character of demonstrative type according to Shmishek (points); SH_V - Shmishek character accentuation indicator (points); SH_DC - indicator of accentuation of character of dysthymic type according to Shmishek (points); SH_EK - an indicator of accentuation of the character of the exalted type according to Shmishek (points).

Table 3. Correlations of anthropo-somatotypological indicators with indicators of the level of subjective control of practically healthy women $(n=101)$.

\begin{tabular}{|c|c|c|c|c|c|c|c|}
\hline \multirow{2}{*}{ Body parameters } & \multicolumn{7}{|c|}{ Indicators of the level of subjective control according to Rotter } \\
\cline { 2 - 8 } & USK_1 & USK_2 & USK_3 & USK_4 & USK_5 & USK_6 & USK_7 \\
\hline OB_GL & 0.20 & 0.19 & 0.24 & 0.08 & 0.20 & 0.13 & 0.01 \\
\hline B_DL_GL & 0.12 & 0.08 & 0.08 & 0.01 & -0.01 & 0.15 & -0.02 \\
\hline N_SH_GL & -0.01 & 0.00 & 0.08 & -0.11 & -0.12 & 0.18 & -0.03 \\
\hline SH_N_CH & -0.12 & -0.16 & 0.14 & -0.15 & -0.17 & 0.15 & 0.00 \\
\hline SAG_DUG & 0.18 & 0.16 & 0.01 & 0.10 & 0.18 & -0.08 & 0.00 \\
\hline B_SH_GL & -0.10 & -0.03 & 0.03 & -0.03 & -0.15 & 0.14 & -0.09 \\
\hline SH_LICA & 0.00 & -0.07 & 0.16 & 0.00 & -0.02 & 0.10 & -0.13 \\
\hline W & -0.05 & -0.02 & 0.13 & -0.06 & -0.03 & 0.10 & -0.18 \\
\hline H & 0.06 & 0.09 & 0.22 & 0.07 & -0.04 & 0.17 & -0.01 \\
\hline ATND & 0.04 & 0.08 & 0.22 & 0.04 & -0.05 & 0.21 & 0.00 \\
\hline ATL & 0.01 & 0.08 & 0.05 & 0.04 & 0.04 & 0.06 & 0.00 \\
\hline ATPL & 0.07 & 0.11 & 0.23 & 0.04 & -0.02 & 0.23 & -0.01 \\
\hline ATP & 0.21 & 0.33 & 0.19 & 0.12 & 0.07 & 0.26 & -0.03 \\
\hline ATV & 0.06 & 0.15 & 0.09 & 0.10 & 0.03 & 0.07 & -0.02 \\
\hline
\end{tabular}


Andriievskyi I. I., Serebrennikova O. A., Gunas I. V., Cherkasova O. V., Kyrychenko V. I.

Continuation of table 3.

\begin{tabular}{|c|c|c|c|c|c|c|c|}
\hline \multirow{2}{*}{ Body parameters } & \multicolumn{7}{|c|}{ Indicators of the level of subjective control according to Rotter } \\
\hline & USK_1 & USK_2 & USK_3 & USK_4 & USK_5 & USK_6 & USK_7 \\
\hline EPPL & 0.04 & 0.10 & 0.04 & -0.02 & 0.02 & 0.15 & 0.06 \\
\hline EPPR & -0.06 & 0.06 & -0.09 & -0.02 & -0.06 & 0.12 & 0.01 \\
\hline EPB & 0.01 & 0.05 & 0.00 & -0.04 & 0.12 & 0.14 & -0.04 \\
\hline EPG & 0.12 & 0.04 & 0.13 & -0.03 & 0.12 & 0.18 & 0.16 \\
\hline $\mathrm{OBPL}_{1}$ & -0.13 & -0.12 & 0.01 & -0.19 & -0.09 & 0.02 & -0.20 \\
\hline $\mathrm{OBPL}_{2}$ & -0.11 & -0.11 & 0.04 & -0.15 & -0.08 & 0.03 & -0.20 \\
\hline $\mathrm{OBPR}_{1}$ & -0.16 & -0.10 & 0.03 & -0.15 & -0.07 & -0.04 & -0.23 \\
\hline $\mathrm{OBPR}_{2}$ & -0.14 & -0.05 & -0.01 & -0.07 & -0.07 & 0.02 & -0.14 \\
\hline OBB & 0.01 & -0.04 & 0.08 & -0.06 & 0.11 & 0.06 & -0.11 \\
\hline $\mathrm{OBG}_{1}$ & -0.11 & -0.11 & 0.02 & -0.10 & -0.04 & -0.04 & -0.13 \\
\hline $\mathrm{OBG}_{2}$ & -0.19 & -0.22 & 0.09 & -0.17 & -0.13 & 0.06 & 0.04 \\
\hline $\mathrm{OBSH}$ & -0.13 & -0.01 & 0.01 & -0.06 & -0.15 & 0.03 & -0.29 \\
\hline OBT & -0.14 & -0.12 & 0.07 & -0.04 & -0.17 & -0.02 & -0.23 \\
\hline OBBB & -0.07 & -0.04 & 0.04 & -0.08 & -0.04 & 0.07 & -0.14 \\
\hline OBK & -0.11 & -0.01 & 0.03 & -0.11 & -0.07 & 0.06 & -0.13 \\
\hline OBS & 0.00 & 0.03 & 0.02 & -0.08 & 0.01 & 0.02 & 0.02 \\
\hline $\mathrm{OBGK}_{1}$ & 0.00 & -0.05 & 0.06 & -0.05 & -0.01 & -0.05 & -0.11 \\
\hline $\mathrm{OBGK}_{2}$ & 0.03 & -0.04 & 0.11 & -0.05 & 0.06 & 0.00 & -0.09 \\
\hline $\mathrm{OBGK}_{3}$ & 0.03 & -0.05 & 0.10 & -0.02 & 0.03 & -0.03 & -0.12 \\
\hline PSG & -0.07 & -0.13 & 0.09 & -0.14 & -0.10 & 0.14 & -0.11 \\
\hline PNG & -0.03 & -0.01 & 0.11 & -0.14 & -0.07 & 0.15 & -0.03 \\
\hline SGK & -0.10 & -0.01 & 0.10 & -0.03 & -0.16 & -0.01 & -0.13 \\
\hline ACR & -0.14 & -0.08 & -0.02 & -0.27 & -0.03 & 0.09 & -0.12 \\
\hline SPIN & -0.06 & -0.10 & 0.13 & 0.10 & -0.11 & 0.02 & 0.00 \\
\hline CRIS & -0.07 & -0.08 & 0.01 & -0.01 & -0.14 & -0.05 & -0.11 \\
\hline TROCH & -0.10 & -0.08 & 0.10 & -0.04 & -0.16 & 0.14 & -0.09 \\
\hline CONJ & -0.18 & -0.15 & 0.11 & -0.03 & -0.21 & 0.05 & -0.14 \\
\hline GZPL & 0.09 & 0.13 & -0.05 & 0.08 & 0.06 & 0.01 & 0.11 \\
\hline GPPL & 0.03 & 0.06 & -0.03 & -0.03 & 0.03 & 0.08 & 0.04 \\
\hline GPR & 0.12 & 0.15 & 0.07 & 0.14 & 0.06 & 0.04 & -0.03 \\
\hline $\mathrm{GL}$ & 0.13 & 0.10 & 0.11 & 0.20 & 0.03 & 0.05 & -0.07 \\
\hline GGR & 0.15 & 0.10 & 0.09 & 0.17 & 0.07 & 0.09 & 0.03 \\
\hline GG & -0.01 & -0.03 & -0.07 & -0.01 & 0.01 & -0.10 & -0.06 \\
\hline GB & 0.07 & 0.02 & 0.07 & 0.13 & -0.03 & -0.05 & -0.09 \\
\hline GBD & -0.09 & -0.04 & -0.17 & -0.17 & -0.07 & -0.07 & -0.05 \\
\hline GGL & -0.06 & 0.00 & -0.18 & -0.13 & 0.03 & -0.11 & 0.00 \\
\hline $\mathrm{FX}$ & 0.15 & 0.12 & 0.08 & 0.15 & 0.07 & 0.02 & -0.05 \\
\hline $\mathrm{MX}$ & -0.11 & -0.10 & -0.11 & -0.16 & 0.01 & -0.03 & -0.11 \\
\hline $\mathrm{LX}$ & 0.09 & 0.08 & 0.04 & 0.10 & 0.00 & -0.01 & 0.18 \\
\hline SOMAT & 0.26 & 0.27 & 0.15 & 0.16 & 0.14 & 0.34 & -0.10 \\
\hline MM & -0.06 & -0.09 & 0.16 & -0.08 & 0.02 & 0.06 & -0.17 \\
\hline
\end{tabular}




\section{Continuation of table 3.}

\begin{tabular}{|c|c|c|c|c|c|c|c|}
\hline \multirow{2}{*}{ Body parameters } & \multicolumn{7}{|c|}{ Indicators of the level of subjective control according to Rotter } \\
\cline { 2 - 9 } & USK_1 & USK_2 & USK_3 & USK_4 & USK_5 & USK_6 & USK_7 \\
\hline OM & -0.01 & 0.06 & 0.02 & -0.15 & 0.00 & 0.23 & 0.03 \\
\hline DM & 0.03 & 0.04 & 0.00 & -0.01 & 0.02 & -0.01 & -0.05 \\
\hline MA & -0.13 & -0.14 & 0.07 & -0.19 & -0.10 & 0.03 & -0.22 \\
\hline
\end{tabular}

Notes: USK_1 - indicator of the scale of general internality of the level of subjective control according to Rotter (scale); USK_2 - indicator of the level of subjective control in the field of achievements according to Rotter (scale); USK_3 - indicator of the level of subjective control in the field of failures according to Rotter (scale); USK_4 - an indicator of the level of subjective control in the field of family relations according to Rotter (scale); USK 5 - an indicator of the level of subjective control in the field of educational (professional) relations according to Rotter (scale); USK_6 - an indicator of the level of subjective control in the field of interpersonal relations according to Rotter (scale); USK_7 - an indicator of the level of subjective control in the field of health and disease according to Rotter (scale).

subjective control in the field of failures according to Rotter with half the longitudinal dimensions of the body $(r=$ from 0.22 to 0.23 ); Spielberger's situational (reactive) anxiety index, or Schmyshek's cyclothymic type accentuation index with all chest girths (respectively, $r=$ from -0.28 to -0.30 and $r=$ from -0.23 to -0.26 ). Also noteworthy are the reliable relationships between the Eysenck scale of neuroticism $(r=-0.24)$, the Spielberger personal anxiety index $(r=-0.28)$ and the indicators of the general internality scale of the level of subjective control, the level of subjective control in the field of achievement and the level of subjective control in the field of interpersonal relations according to Rotter $(r=$ from 0.26 to 0.34 ) with the type of somatotype.

Quantitative analysis of significant correlations between anthropo-somatotypological indicators and indicators of personality traits of practically healthy Ukrainian women revealed the following distribution of connections:

- with the leading typological characteristics of temperament according to Eysenck 8 weak strength correlations out of 174 possible (4.60\%), of which, $1.15 \%$ direct and $3.45 \%$ inverse, among which - with cephalometric indicators 1 feedback out of 21 possible $(4.76 \%)$ ); with longitudinal body sizes 1 feedback out of 18 possible (4.76\%); with body circumference 3 correlations out of 45 possible (4.44\% direct and $2.22 \%$ reverse); with transverse body sizes 2 feedback out of 24 possible $(8.33 \%)$; with somatotypological indicators 1 feedback out of 12 possible $(8.33 \%)$;

- with psychodynamic features of the personality according to Spielberger 7 correlations from 116 possible $(6.03 \%)$, from which, $0.86 \%$ of direct weak force, $1.72 \%$ feedback of average force and $3.45 \%$ feedback of weak force, among which - with girth sizes of a body of 4 correlations out of 30 possible $(6.67 \%$ feedback of medium strength and $6.67 \%$ feedback of weak strength); with TSFF 1 feedback of weak force correlation from 18 possible (5.56 \%); with somatotypological indicators 2 weak forces correlations out of 8 possible (12.50\% direct and $12.50 \%$ reverse);

- with indicators of severity and features of accentuated personality traits according to Shmishek 28 weak correlations out of 580 possible (4.83\%), of which, $0.52 \%$ direct and $4.31 \%$ reverse, among which - with cephalometric indicators 5 weak correlations out of 70 possible $(1.43 \%$ direct and $5.71 \%$ reverse); with longitudinal body size 5 inverse weak strength correlations out of 60 possible $(8.33 \%)$; with the width of the distal epiphyses of the extremities 3 inverse weak correlations out of 40 possible $(7.50 \%)$; with girth body size 7 weak strength correlations out of 150 possible (1.33\% direct and $3.33 \%$ reverse); with transverse body size 4 inverse weak strength correlations out of 80 possible $(5.0 \%)$; with TSFF 4 reverse weak correlations out of 90 possible $(4.44 \%)$;

- with indicators of the level of subjective control according to Rotter 17 correlations out of 406 possible (4.19\%), of which, $0.49 \%$ of direct medium strength, $2.22 \%$ of direct weak force and $1.48 \%$ of reverse weak force, among which with cephalometric indicators 1 direct weak correlation from 49 possible (2.04\%); with longitudinal body size 6 direct correlations out of 42 possible $(2.38 \%$ of medium strength and $11.9 \%$ of weak strength); with girth body size of 4 inverse weak strength correlations out of 105 possible (3.81\%); with transverse body size 1 reverse weak force correlation out of 56 possible (1.79\%); with somatotypological indicators of 3 direct correlations out of 28 possible (3.57\% of medium strength and $7.14 \%$ of weak strength); with indicators of the component composition of body weight 2 weak correlation strength out of 28 possible ( $3.57 \%$ direct and $3.57 \%$ reverse).

One of the areas where the relationship between anthropo-somatometric indicators and human personality traits is actively studied is sports medicine. Indian researchers surveyed 120 people in water sports and 120 people in non-water sports to find data. Indicators of personality traits were determined by the method of John and Srivastava, and somatotype by Heath and Carter. Positive correlations between indicators of conscientious personality traits and endo-, ecto- and mesomorphic somatotypes were revealed. Water endomorph players had higher personal integrity scores than mesomorphs and ectomorphs [12].

Yutkina O. S. [31] determined the dependence of the level of alexithymia in adolescents on the degree of physical development. The level of alexithymia was determined using an adapted TAS scale. Statistical processing revealed that adolescents with a level of physical development above or below average can be attributed to the risk group of alexithymia $(p<0.05)$. 
It was found that alexithymic radical in students was observed in $56 \%$ of cases in persons with abdominal somatotype, in $39 \%$ of indeterminate somatotype, $36 \%$ of thoracic and $28 \%$ of muscular somatotypes [22].

Correlations between somatotype and personality traits in preschool twins have been studied. The study involved 124 pairs of twins under the age of 7 years. Significant correlations between ectomorphic somatotype and indicators of adaptability $(p<0.01)$, negative correlations between endomorphic somatotype and level of activity, adaptability and stability $(p<0.01)$ were revealed. However, no association was found between somatotype and temperament type $(p>0.05)$ [32].

It was found that the ratio of width and height of the face has significant positive correlations with indicators of dominance, factor self-centered impulsivity and general indicators of psychopathy [1].

Korsak V. O. and Khromenkova Yu. Yu. [13] conducted psychodiagnostic and anthropometric examination of 31 boys and 33 girls in order to determine the relationships between the studied indicators. The results of the study showed a much smaller number of such correlations in boys compared to girls. For girls, the anthropometric markers of personality traits associated with heteroaggression are the Pin? index and waist and hips, and for depressivesuicidal - the ratio of the length of 4 finger of the left hand to the length of the body.

In addition, both domestic and foreign groups of researchers have established relationships between dermatoglyphic indicators and indicators of human personality $[10,20,27]$.

A survey of young men in Zheleznogorsk found that $38.89 \%$ of asthenics are dominated by high extraversion, medium and very high emotional balance and plasticity. Normosthenics are dominated by high and very high extraversion (35.48\%); at picnics this data is $26.68 \%$ [19].

A study of school-age people in the Grodno region revealed that in asthenic girls there is a strong correlation with choleric and sanguine temperament types, and in boys between normosthenic body type and choleric temperament [23].

Eroputko S. V. and Yutkina O. S. [8] established the distribution of accentuators depending on age, sex and somatotype. Thus, at the age of 10-14 years in girls, hyperthymia is most common in individuals with macrosomatotype, and exaltation and cyclothymia in individuals with microsomatotype $(p<0.05)$. At the age of $15-$ 18 years, excitability, exaltation and cyclothymia predominate in girls with microsomatotype $(p<0.05)$, in persons with mesosomatotype - emotionality, and in persons with macrosomatotype - cyclothymic and emotionality $(p<0.05)$.

Given a number of previous studies [2, 11, 26, 28],

\section{References}

[1]Anderl, C., Hahn, T., Schmidt, A. K., Moldenhauer, H., Notebaert, K., Clement, C. C., \& Windmann, S. (2016). Facial width-toheight ratio predicts psychopathic traits in males. Personality conducted on the basis of the research center of National Pirogov Memorial Medical University, Vinnytsya, in which there were pronounced changes in correlations (strength, and sometimes direction) of the constitutional size of the body with the size of internal organs or functional indicators of organs and systems of the body between practically healthy population in general compared to it in the distribution of different somatotypes, in further research it is necessary to determine the features of correlations between anthroposomatotypological indicators and indicators of personality traits of practically healthy Ukrainian women of different somatotypes.

\section{Conclusions}

1. In practically healthy Ukrainian women of the first mature age there are mostly single reliable weak strength inverse and direct correlations between anthroposomatotypological indicators and indicators of personality traits (according to Eysenck, Spielberger and Shmishek mostly inverse, and according to Rotter - mostly direct).

2 . The multiple character of reliable correlations is established only between the index of accentuation of the character of the exalted type according to Shmishek with the majority of indicators of the width of the distal epiphyses of the extremities and the size of the pelvis; between the level of subjective control in the field of failures according to Rotter with half the longitudinal size of the body; between the indicator of situational (reactive) anxiety according to Spielberger, or the indicator of accentuation of the character of the cyclothymic type according to Shmishek with all the girths of the chest.

3. As a result of quantitative analysis of significant correlations between anthropo-somatotypological indicators and indicators of personality traits of practically healthy Ukrainian women, it was found that the percentage of such relationships ranges from $4.19 \%$ with indicators of subjective control over Rotter to $6.03 \%$ with psychodynamic personality traits according to Spielberger.

4. Among anthropo-somatotypological indicators, the largest relative percentage of reliable correlations was found: with the leading typological characteristics of temperament according to Eysenck - with transverse body size and with somatotypological indicators (8.33\% each); with psychodynamic features of personality according to Spielberger - with somatotypological indicators (25.0\%); with indicators of severity and features of accentuated personality traits according to Shmishek - with longitudinal body size $(8.33 \%)$, cephalometric indicators $(7.14 \%)$ and width of the distal epiphyses of the extremities $(7.50 \%)$; with indicators of the level of subjective control according to Rotter - with longitudinal body size $(14.29 \%)$ and somatotypological indicators $(10.71 \%)$.

and Individual Differences, 88, 99-101. doi: 10.1016/ j.paid.2015.08.057

[2] Antonets, O. V., Gunas, I. V., Kryvko, Yu. Ya., Prokopenko, S. V., 
\& Glushak, A. A. (2017). Connections sonographic parameters of spleen with indicators of structure and size of the body in almost healthy women with different somatotype. Reports of Morphology, 23(1), 84-89.

[3] Avabde, D. S., Piskareva, S. A., Gvardeeva, S. G., \& Ageeva, Y. S. (2019). Characteristics of the constitution and type of temperament in adolescents, depending on gender and climate. Siberian Journal of Life Sciences and Agriculture, 11(5-1), 12-16. doi: 10.12731/2658-6649-2019-11-5-12-16

[4] Bunak, V. V. (1941). Anthropometry: a practical course. M.: Uchpedgiz.

[5] Carter, J. L., \& Heath, B. H. (1990). Somatotyping - development and applications. Cambridge University Press.

[6] Dubrovina I. V. (1995). Guide practical psychologist: the mental health of children and adolescents in the context of psychological services. Moscow: Academy.

[7] Eliseev, O. P. (2010). Workshop on psychology. St. Petersburg: Peter.

[8] Eroputko, S. V., \& Omelich, Y. V. (2018). Analysis of personality accentuations in adolescents based on the Leonhard-Shmishek test. In Youth of the XXI century: a step into the future (pp. 257258).

[9] Golovei L. A., \& Rybalko E. F. (2002). Workshop on age psychology. St. Petersburg: Speech.

[10] Gunas, V. I. (2019). Correlations of indices of personality traits with indexes of finger and palmar dermatoglyphics of practically healthy Ukrainian men. Biomedical and Biosocial Anthropology, (34), 20-25. doi: 10.31393/bba34-2019-03

[11] Gunas, I. V., Prokopenko, S. V., Antonets, O. V., \& Dmytrenko, S. V. (2017). Relationships of sonographic parameters of the spleen with the constitutional parameters of the body of almost healthy men of different somatotypes. World of Medicine and Biology, 2(60), 25-28.

[12] Hooda, H. (2019). Conscientiousness personality trait in relation to anthropometric somatotype of aquatic and non-aquatic players. International Journal of Physiology, Nutrition and Physical Education, 4(1), 2037-2041.

[13] Korsak, V. O., \& Khromenkova, Y. Y. (2015). Anthropometric markers of mental and behavioral characteristics of boys and girls. In Bulletin of Medical Internet Conferences (Vol. 5, No. 5 , pp. 654-658). Limited Liability Company Science and Innovation.

[14] Krylov, A. A. (1990). Workshop on Experimental and Applied Psychology. L.: Publishing House of the Leningrad University.

[15] Mantarkov, M., Ahmed-Popova, F., Akabaliev, V., \& Sivkov, S. (2016). Somatotype in Bipolar Disorder Revisited: Gender Differences, Neurodevelopment and Clinical Implications. Imperial Journal of Interdisciplinary Research (IJIR), 2(9), 1028-1037.

[16] Mantarkov, M., Nonchev, P., \& Stoyanov, D. (2013). Sexual dimorphism and the correlation structure of the somatotype of mentally healthy individuals. Psychiatry and psychopharmacotherapy, 15(4), 69-74.

[17] Matiegka, J. (1921). The testing of physical efficiency. Am. J. Phys. Antropol, 2(3), 25-38. doi: 10.1002/ajpa.1330040302

[18] Miroshnikov, S. A., Kravets, O. Iu., Filippova, M. G., \& Chernov, R. V. (2006). Appendix to the methodological materials of the expert system of individual support "Longitude": description of the additions to the extended version "Longituyd+". St.
Petersburg.

[19] Moskalenko, O. L. (2015). Characteristics of the properties of temperament in young male students of different somatotypes in Zheleznogorsk. In the World of Scientific Discoveries, 68, 442-449.

[20] Negasheva, M. A. (2008). The relationship of somatic, dermatoglyphic and psychological signs in the structure of the general constitution of a person from the standpoint of a systematic approach. Morphology, 133(1), 73-77.

[21] Pailhez, G., \& Bulbena, A. (2010). Body shape and psychiatric diagnosis revisited. International Journal of Psychiatry in Clinical Practice, 14(4), 236-243. doi: 10.3109/ 13651501.2010.505344

[22] Pashkova, I. G., Kudryashova, S. A., Kolupaeva, T. A., \& Belousova, G. P. (2011). The physique and body composition of young men, taking into account the psychological characteristics of the personality in the conditions of the North. Scientific notes of St.P. SMU named after I. P. Pavlov, 18(2), 111-112.

[23] Radiyevskiy, D. L. (2010). Characteristics of somatotypes, types of temperament and connections between them in schoolchildren of the Grodno region. Collection of scientific works, Grodno, 30-34.

[24] Raigorodskii, D. la. (2004). Practical psychodiagnostics. Methods and tests. Samara: Publishing House "Bahrah-M".

[25] Rogov, E. I. (1996). Handbook of practical psychologist in education. M.: "Vlados".

[26] Semenchenko, V. V. (2018). Correlation of anthroposomatometric parameters of the body of practically healthy women of the ectomorphic somatotype with cerebral blood circulation indicators. Biomedical and biosocial anthropology, 30, 27-35. doi: 10.31393/bba30-2018-04

[27] Serebrennikova, O. A., Gunas, V. I., Klimas, L. A., Ocheretna, N. P., \& Shayuk, A. V. (2019). Predictive assessment of the association of dermatoglyphic indicators with indicators of personality traits, established by factor analysis. Reports of Morphology, 25(1), 12-18. doi: 10.31393/morphology-journal2019-25(1)-02

[28] Serebrennikova, O. A., Semenchenko, V. V., Dmytrenko, S. V., Semenenko, A. I., Ocheretna, O. L., Maievskyi, O. Ye., \& Shayuk, A. V. (2018). Correlation constitutional parameters of a body in practically healthy women of middle intermediate somatotypes with rheoencephalography indicators. World of Medicine and Biology, 1(63), 75-78. doi: 10.26724/2079-8334-2018-1-63-75-78

[29] Shephard, R. J. (2005). Body composition in biological anthropology. Cambridge University Press, Cambridge, UK; New York. https://www.nhbs.com/body-composition-in-biologicalanthropology-book

[30] World Health Organization. (2001). The World Health Report 2001: Mental health: new understanding, new hope. World Health Organization.

[31] Yutkina, O. S. (2016). Psychological characteristics of schoolboys depending on somatotype. Amur Medical Journal, 3-4(15-16), 124-125. doi: 10.22448/AMJ.2016.15-16.124-125

[32] Zhao, M., Li, Y. L., \& Zheng, Y. N. (2014, January). Correlations between Somatotype and Temperament in Pre-School Twins. In 2014 International Conference on Management, Education and Social Science (ICMESS 2014). Atlantis Press. doi: 10.2991/icmess-14.2014.42

\section{КОРЕЛЯЦІЇ АНТРОПО-СОМАТОТИПОЛОГІЧНИХ ПОКАЗНИКІВ ІЗ ПОКАЗНИКАМИ ОСОБЛИВОСТЕЙ ОСОБИСТОСТІ ПРАКТИЧНО ЗДОРОВИХ УКРАЇНСЬКИХ ЖІНОК}

Андрієвський І. І., Серебреннікова О. А., Гунас І. В., Черкасова О. В., Кириченко В. І.

Мета роботи - визначити та провести аналіз особливостей кореляцій між конституціональними параметрами тіла та показниками особливостей особистості практично здорових українських жінок першого зрілого віку. Первинні антропо- 
соматотипологічні (антропометричне обстеження за схемою В. В. Бунака, визначення соматотипу - за математичною схемою J. Carter i B. Heath; визначення жирового, кісткового і м'язового компонентів маси тіла - за формулами J. Маtiegka, визначення м'язового компонентів маси тіла - за методом Американського інституту харчування) та показники особливостей особистості (провідні типологічні характеристики темпераменту за Айзенком, психодинамічні особливості особистості за Спілбергером, показники вираженості та особливості акцентуйованих рис особистості за Шмішеком, показники рівня суб'єктивного контролю за Роттером) 101 практично здорової української жінки першого зрілого віку відібрані з банку даних матеріалів науково-дослідного центру Вінницького національного медичного університету ім. М. І. Пирогова. Аналіз кореляцій між антропо-соматотипологічними показниками та показниками особливостей особистості проводили в ліцензійному пакеті "Statistica 6.1" з використанням статистичного методу Пірсона. Між антропо-соматотипологічними показниками та показниками особливостей особистості практично здорових українських жінок встановлені переважно поодинокі слабкої сили зворотні та прямі достовірні зв'язки. У більшості випадків зворотні зв'язки встановлені з провідними типологічними характеристиками темпераменту за Айзенком, психодинамічними особливостями особистості за Спілбергером та показниками вираженості й особливостями акцентуйованих рис особистості за Шмішеком, а прямі - з показниками рівня суб'єктивного контролю за Роттером. Множинний характер зв'язків лише між показником акцентуації характеру екзальтованого типу за Шмішеком із більшістю показників ширини дистальних епіфрізів кінцівок і розмірів таза; між показником рівня суб'єктивного контролю в галузі невдач за Роттером із половиною поздовжніх розмірів тіла; між показником ситуативної (реактивної) тривожності за Спілбергером, або показником акцентуації характеру циклотимного типу за Шмішеком із усіма обхватами грудної клітки. Кількісний аналіз достовірних кореляцій між антропо-соматотипологічними показниками та показниками особливостей особистості практично здорових українських жінок дозволив виявити найбільиий відносний відсоток достовірних кореляцій антропо-соматотипологічних показників. А саме, із провідними типологічними характеристиками темпераменту за Айзенком найбільший відносний відсоток достовірних зв'язків встановлено з поперечними розмірами тіла та з соматотипологічними показниками; із психодинамічними особливостями особистості за Спілбергером - із соматотипологічними показниками; із показниками вираженості та особливостями акцентуйованих рис особистості за Шмішеком - із поздовжніми розмірами тіла, кефралометричними показниками та шириною дистальних епіфізів кінцівок; із показниками рівня суб'єктивного контролю за Роттером - із поздовжніми розмірами тіла та соматотипологічними показниками. Ключові слова: кореляції, антропометричні та соматотипологічні показники, показники особливостей особистості, практично здорові жінки першого зрілого віку.

\section{КОРРЕЛЯЦИИ АНТРОПО-СОМАТОТИПОЛОГИЧЕСКИХ ПОКАЗАТЕЛЕЙ С ПОКАЗАТЕЛЯМИ ОСОБЕННОСТЕЙ ЛИЧНОСТИ ПРАКТИЧЕСКИ ЗДОРОВЫХ УКРАИНСКИХ ЖЕНЩИН \\ Андриевский И. И., Серебренникова О. А., Гунас И. В., Черкасова Е. В., Кириченко В. И.}

Цель работы - определить и провести анализ особенностей корреляций между конституциональными параметрами тела и показателями особенностей личности практически здоровых украинских женщин первого зрелого возраста. Первичные антропо-соматотипологические (антропометрическое обследование по схеме В. В. Бунака, определение соматотипа - по математической схеме J. Carter и B. Hеath; определение жирового, костного и мышечного компонентов массы тела - по формулам J. Matiegka, определение мышечного компонента массы тела - по методу Американского института питания) и показатели особенностей личности (ведущие типологические характеристики темперамента по Айзенку, психодинамические особенности личности по Спилбергеру, показатели выраженности и особенности акцентуированных черт личности по Шмишеку, показатели уровня субъективного контроля по Роттеру) 101 практически здоровой украинской женщины первого зрелого возраста отобраны из банка данных материалов научно-исследовательского центра Винницкого национального медицинского университета им. Н. И. Пирогова. Анализ корреляций между антропо-соматотипологическими показателями и показателями особенностей личности проводили в лицензионном пакете "Statistica 6.1" с использованием статистического метода Пирсона. Между антропо-соматотипологическими показателями и показателями особенностей личности практически здоровых украинских женщин установлены преимущественно одиночные слабой силы обратные и прямые достоверные связи. В большинстве случаев обратные связи установлены с ведущими типологическими характеристиками темперамента по Айзенку, психодинамическими особенностями личности по Спилбергеру и показателями выраженности и особенностями акцентуированных черт личности по Шмишеку, а прямые - с показателями уровня субъективного контроля по Роттеру. Множественный характер связей только между показателем акцентуации характера экзальтированного типа по Шмишеку с большинством показателей ширины дистальных эпифизов конечностей и размеров таза; между показателем уровня субъективного контроля в области неудач по Роттеру с половиной продольных размеров тела; между показателем ситуативной (реактивной) тревожности по Спилбергеру, или показателем акцентуации характера циклотимного типа по Шмишеку со всеми обхватами грудной клетки. Количественный анализ достоверных корреляций между антропосоматотипологическими показателями и показателями особенностей личности практически здоровых украинских женщин позволил выявить наибольщий относительный процент достоверных корреляций антропо-соматотипологических показателей. А именно, с ведущими типологическими характеристиками темперамента по Айзенку наибольший относительный процент достоверных связей установлен с поперечными размерами тела и с соматотипологическими показателями; с психодинамическими особенностями личности по Спилбергеру - с соматотипологическими показателями; с показателями выраженности и особенностями акцентуированных черт личности по Шмишеку - с продольными размерами тела, кефралометрическими показателями и шириной дистальных эпифизов конечностей; с показателями уровня субъективного контроля по Роттеру - с продольными размерами тела и соматотипологическими показателями.

Ключевые слова: корреляции, антропометрические и соматотипологические показатели, показатели особенностей личности, практически здоровые женщины первого зрелого возраста. 